\title{
Efektivitas sabun antiseptik dalam menghambat pertumbuhan Escherichia coli dan Salmonella typhi
}

\author{
Anastasia Kristy, Adhayani Lubis*, Armon Rahimi, Rico Alexandre, Janice, Anita Rosari, \\ Fransiska Kotsasi, Gede Pardianto \\ Fakultas Kedokteran Universitas Prima Indonesia \\ *Korespondensi: adhayaniadhayani@gmail.com \\ DOI: $10.34012 / j p m s . v 3 i 1.1788$ \\ (C) 2021 JPMS. All rights reserved
}

\begin{abstract}
Abstrak
Tujuan dari penelitian ini adalah untuk menguji daya hambat sabun antiseptik dalam menghambat pertumbuhan bakteri Escherichia coli dan Salmonella typhi. Sampel yang dipakai adalah sebanyak 4 sabun antiseptik (sabun A, B, C dan D) dengan masing-masing konsentrasi sebesar 10\%, 20\%, 30\% dan $40 \%$. Proses pengenceran sesuai dengan konsentrasinya dapat mengubah kemampuan sabun dalam menghambat pertumbuhan bakteri yang diuji dengan metode difusi. Hasil penelitian didapatkan bahwa keempat sampel sabun antiseptik memiliki efektivitas antibakteri terhadap Escherichia coli dan Salmonella typhi. Namun pada Escherichia coli, rata-rata diameter zona hambat yang paling besar adalah pada sabun antiseptik A dengan konsentrasi $40 \%$ yaitu $26 \mathrm{~mm}$ dan rata-rata diameter zona hambat paling kecil adalah pada sabun antiseptik D dengan konsenstrasi $10 \%$ yaitu $7 \mathrm{~mm}$. Sedangkan pada Salmonella typhi rata-rata diameter zona hambat paling besar adalah pada sabun antiseptik $A$ dengan konsentrasi $40 \%$ yaitu $20 \mathrm{~mm}$ dan rata-rata diameter zona hambat paling kecil adalah pada sabun antiseptik B dengan konsentrasi $10 \%$ yaitu $10 \mathrm{~mm}$. Hal tersebut dapat terjadi karena dinding penyusun dari kedua bakteri tersebut berbeda dan kandungan dari masing-masing sabun juga berbeda.
\end{abstract}

Kata kunci: sabun antiseptik, Escherichia coli, Salmonella typhi

\begin{abstract}
The purpose of this study was to test the inhibitory power of antiseptic soap in inhibiting the growth of Escherichia coli and Salmonella typhi bacteria. The samples used were 4 antiseptic soaps (soap $A, B, C$ and D) with each concentration of $10 \%, 20 \%, 30 \%$ and $40 \%$. The dilution process according to the concentration can change the soap's ability to inhibit the growth of bacteria tested by the diffusion method. The results showed that the four samples of antiseptic soap had antibacterial effectiveness against Escherichia coli and Salmonella typhi. However, in Escherichia coli, the largest average diameter of the inhibition zone is antiseptic soap A with a concentration of $40 \%$, which is $26 \mathrm{~mm}$ and the smallest average diameter of the inhibition zone is antiseptic soap $D$ with a concentration of $10 \%$, which is $7 \mathrm{~mm}$. Meanwhile, for Salmonella typhi, the average diameter of the largest inhibition zone is antiseptic soap A with a concentration of $40 \%$, which is $20 \mathrm{~mm}$, and the average diameter of the smallest inhibition zone is antiseptic soap B with a concentration of $10 \%$, which is $10 \mathrm{~mm}$. This can happen because the constituent walls of the two bacteria are different and the content of each soap is also different.
\end{abstract}

Keywords: antiseptic soap, Escherichia coli, Salmonella typhi

\section{Pendahuluan}

Segala macam infeksi dapat terjadi pada manusia baik dari bakteri eksogen maupun endogen. Infeksi tersebut dapat menyebabkan berbagai macam penyakit seperti infeksi pada saluran pencernaan yaitu diare dan demam tifoid. Penyakit ini sering disebabkan oleh bakteri patogen seperti Escherichia coli dan
Salmonella typhi. ${ }^{1}$ Bakteri Escherichia coli merupakan bakteri yang paling sering menyerang saluran pencernaan dan bakteri ini merupakan penyebab umum terjadinya diare di seluruh dunia. ${ }^{2}$ Menurut WHO bahwa sebanyak 2,2 juta penduduk di dunia meninggal dunia akibat diare. Pada tahun 2013 lebih dari 750.000 anakanak di bawah 5 tahun meninggal setiap tahun- 
nya. Lebih dari setengah kasus diare terjadi di benua Afrika dan Asia dengan jumlah sebanyak 783 juta kasus di Asia dan 696 juta kasus di Afrika. $^{3}$

Selain bakteri Escherichia coli, Salmonella typhi juga dapat menginfeksi saluran pencernaan dan merupakan penyebab terjadinya demam tifoid. Demam tifoid adalah suatu penyakit sistemik di mana bakteri tersebut menyerang saluran pencernaan yang biasanya terinfeksi secara fecal-oral. Demam tifoid dapat menimbulkan gejala demam enterik yang berlangsung beberapa minggu dan konstipasi yang dapat kemudian menjadi diare berdarah. ${ }^{4}$

Menurut kajian Morbiditas Diare Indonesia 2012, jumlah penderita diare pada semua umur sebanyak 214 orang per 1.000 penduduk dan penderita diare pada balita adalah sebanyak 900 orang per 1.000 penduduk. Pada tahun 2015 terjadi 18 Kejadian Luar Biasa (KLB) diare yang tersebar di 11 propinsi yaitu propinsi yang tertinggi adalah Sumatera Utara dengan jumlah penderita 490 orang dan jumlah kematian 14 orang. Sementara di posisi kedua adalah propinsi Nusa Tenggara Timur, ketiga adalah Jawa Tengah, ke empat Sulawesi Tenggara dan Lampung di posisi ke lima. ${ }^{5}$

Diare adalah defekasi dengan feses berbentuk cair atau setengah cair yang diakibatkan karena kuman enteropatogen meliputi penempelan bakteri pada sel epitel dengan atau tanpa kerusakan mukosa, invasi mukosa dan produksi enterotoksin atau sitotoksin. Namun pada umumnya, diare dapat diatasi dengan penggantian cairan dan elektrolit yang dihitung berdasarkan berat badan serta pemberian antibiotika. Penularan diare melalui jalur fekaloral, penularan dapat dicegah dengan menjaga kebersihan yaitu mencuci tangan setelah keluar dari toilet dan khususnya selama mengolah makanan. ${ }^{6}$

Survei Global Burden of Disease (GBD) menunjukkan pada tahun 2010 penderita demam tifoid mencapai 12,2 juta orang dengan angka kematian sebanyak 190,200 jiwa. Sekitar $80 \%$ kasus demam tifoid dilaporkan menjangkit penduduk di benua Asia dan Afrika. Pada beberapa negara di Asia terdapat perkembangan bakteri Salmonella paratyphi A pada penderita demam tifoid. ${ }^{7}$

Menurut WHO 2008, penderita dengan demam tifoid di Indonesia tercatat 81,7 per
100.000. ${ }^{8}$ Profil Kesehatan Indonesia tahun 2010 menunjukkan penderita demam tifoid dan paratifoid yang dirawat inap di rumah sakit sebanyak 41.081 kasus dan 279 di antaranya meninggal dunia. ${ }^{9}$

Menurut sebuah studi di Amerika dengan mencuci tangan sesuai dengan prosedur yang tepat dapat mengurangi risiko terjangkitnya diare dan demam tifoid. Namun sampai sekarang belum ada angka pasti seberapa banyak jumlah sabun antiseptik yang diperlukan untuk menghentikan transmisi dari bakteri patogen tersebut. ${ }^{2}$ Namun menurut Centers for Disease Control (2015) bahwa dengan mencuci tangan dengan sabun antiseptik dapat mengurangi seseorang terjangkitnya diare dan demam tifoid sebesar $31 \%$ dan sebesar $58 \%$ pada orang dengan kondisi imunokompromais. ${ }^{10}$

Penelitian Fitri (2010) menunjukkan bahwa sabun cuci tangan antiseptik memiliki efek daya hambat bakteri yang baik terhadap beberapa bakteri patogen karena di dalam sabun antiseptik mengandung komposisi tambahan yang bekerja untuk menghambat pertumbuhan bakteri yaitu triclosan dan chloroxylenol di mana dalam penelitian tersebut diperoleh bahwa suspensi sabun dengan konsentrasi $50 \%$ dapat membentuk zona hambat terhadap pertumbuhan bakteri dengan rata-rata diameter sebesar $15,6 \mathrm{~mm}, 11,5 \mathrm{~mm}, 9,83 \mathrm{~mm}$ dan 25,16 mm. Pemberian akuades sebagai kontrol negatif memiliki rata-rata sebesar $5,00 \mathrm{~mm}$ sedangkan pemberian fenol $2 \%$ sebagai kontrol positif membentuk zona hambat dengan diameter rata-rata $15,00 \mathrm{~mm} \cdot{ }^{11}$ Adapun klasifikasi respon hambatan pertumbuhan bakteri adalah jika zona hambat $>20 \mathrm{~mm}$ maka respon hambatan bakteri kuat, sementara itu jika zona hambat 16-19 mm maka respon hambatan bakteri sedang, kemudian jika zona hambat $11-15 \mathrm{~mm}$ maka respon hambatan bakteri lemah dan jika zona hambat $<10 \mathrm{~mm}$ maka respon hambatan bakteri tidak ada. ${ }^{12}$

Penelitiian ini bertujuan untuk mengetahui efektivitas semua sabun antiseptik dalam menghambat pertumbuhan bakteri patogen seperti Escherichia coli dan Salmonella typhi.

\section{Metode}

Penelitian ini merupakan penelitian eksperimental laboratorium dengan metode uji sensitivitas (metode disc diffusion). Sampel yang 
digunakan adalah 4 buah sabun antiseptik (sabun cair A, sabun cair B, sabun cair $C$, dan sabun cair D). Metode yang digunakan dalam sampling adalah metode rancangan acak kelompok sub sampling, dengan 6 perlakuan yaitu sabun $A, B, C$, dan $D$ dengan konsentrasi $10 \%$, 20\%, 30\%, 40\%, kontrol negatif (akuades) dan kontrol positif (fenol 2\%). Masing-masing perlakuan diulang sebanyak 3 kali. Alat-alat yang digunakan dalam penelitian ini adalah oven, timbangan, pengaduk, cawan petri steril, tabung reaksi, pipet ukur, batang penyebar, pinset, autoklaf, inkubator, jarumose, kompor listrik, labu Erlenmeyer, gelas ukur, lampu spiritus, jangka sorong dan spidol. Bahan-bahan yang digunakan dalam penelitian ini adalah 4 sampel sabun yang akan diperiksa (sabun A, sabun $B$, sabun $C$ dan sabun $D)$, media Nutrient Agar (NA), biakan bakteri Escherichia coli dan Salmonella typhi yang berumur 24 jam, tetrasiklin, akua dessteril, kertas cakram kosong, larutan pembanding McFarland 0,5 dan alkohol 70\%, kapas, kertas label dan alumunium foil. Data diuji menggunakan uji Kruskall-Walis untuk melihat adanya hubungan antara senyawa triclosan, chlorxylenol, triclocarban dan sodium benzoate terhadap pertumbuhan bakteri Escherichia coli dan Salmonella typhi.

\section{Hasil}

Uji efektivitas antibakteri sabun antiseptik terhadap pertumbuhan Escherichia coli dan Salmonella typhi dengan menggunakan uji sensitivitas ditunjukkan dengan adanya zona hambat atau zona bening di sekitar kertas cakram. Diameter zona hambat diukur dengan menggunakan jangka sorong. Hasil uji efektivitas antibakteri sabun antiseptik A terhadap Escherichia coli pada konsentrasi masing-masing 10\%, 20\%, 30\% dan 40\% dengan rata-rata diameter zona hambat sebesar 21 $\mathrm{mm}, 22 \mathrm{~mm}, 23 \mathrm{~mm}$ dan $26 \mathrm{~mm}$. Sedangkan pada sabun antiseptik B pada konsentrasi masing-masing $10 \%, 20 \%, 30 \%$ dan $40 \%$ dengan rata-rata diameter zona hambat sebesar 20 $\mathrm{mm}, 21 \mathrm{~mm}, 22 \mathrm{~mm}$ dan $23 \mathrm{~mm}$. Pada sabun antiseptik $C$ dengan konsentrasi masing-masing $10 \%, 20 \%, 30 \%$ dan $40 \%$ dengan rata-rata diameter zona hambat sebesar $18 \mathrm{~mm}, 17 \mathrm{~mm}$, $19 \mathrm{~mm}$ dan $20 \mathrm{~mm}$ serta pada sabun antiseptik D pada konsentrasi masing-masing $10 \%, 20 \%$, $30 \%$ dan $40 \%$ dengan rata-rata diameter zona hambat sebesar $7 \mathrm{~mm}, 8 \mathrm{~mm}, 9 \mathrm{~mm}$ dan $12 \mathrm{~mm}$. Rata-rata diameter zona hambat paling besar adalah pada sabun antiseptik $A$ dengan konsentrasi $40 \%$ yaitu $26 \mathrm{~mm}$ dan rata-rata diameter zona hambat paling kecil adalah pada sabun antiseptik $D$ dengan konsenstrasi $10 \%$ yaitu $7 \mathrm{~mm}$. Pada kontrol positif (Tetrasiklin) didapatkan rata-rata diameter zona hambat sebesar $24 \mathrm{~mm}$, sedangkan pada kontrol negatif tidak terdapat zona hambat.

Tabel 1. Hasil diameter zona hambat sabun antiseptik $A, B, C$ dan $D$ terhadap bakteri Escherichia coli

\begin{tabular}{|c|c|c|c|c|c|c|c|c|c|c|c|c|}
\hline \multirow{3}{*}{ Perlakuan } & \multicolumn{12}{|c|}{ Diameter Zona Hambat (mm) Terhadap Escherichia coli } \\
\hline & \multicolumn{3}{|c|}{ Sabun A } & \multicolumn{3}{|c|}{ Sabun B } & \multicolumn{3}{|c|}{ Sabun C } & \multicolumn{3}{|c|}{ Sabun D } \\
\hline & $\mathbf{I}$ & II & III & $\mathbf{I}$ & II & III & $\mathbf{I}$ & II & III & $\mathbf{I}$ & II & III \\
\hline $10 \%$ & 17 & 24 & 22 & 20 & 19 & 21 & 21 & 15 & 16 & 7 & 7 & 7 \\
\hline $20 \%$ & 21 & 24 & 21 & 25 & 21 & 17 & 23 & 12 & 18 & 8 & 8 & 8 \\
\hline $30 \%$ & 24 & 24 & 22 & 24 & 20 & 21 & 24 & 13 & 20 & 9 & 9 & 9 \\
\hline $40 \%$ & 27 & 25 & 25 & 27 & 23 & 18 & 23 & 17 & 19 & 12 & 12 & 12 \\
\hline $\mathrm{K}(+)$ Tetrasiklin & \multicolumn{12}{|c|}{24} \\
\hline $\mathrm{K}(-)$ Akuades & \multicolumn{12}{|c|}{0} \\
\hline
\end{tabular}

Tabel 2. Rata-rata diameter zona hambat sabun antiseptik A, B, C dan D terhadap bakteri Escherichia coli

\begin{tabular}{ccccc}
\hline \multirow{2}{*}{ Konsentrasi } & \multicolumn{4}{c}{ Rata-Rata Diameter Zona Hambat (mm) terhadap } \\
& \multicolumn{5}{c}{ Escherichia coli } \\
\cline { 2 - 5 } & Sabun A & Sabun B & Sabun C & Sabun D \\
\hline $\mathbf{1 0 \%}$ & 21 & 20 & 17 & 7 \\
$\mathbf{2 0 \%}$ & 22 & 21 & 18 & 8 \\
$\mathbf{3 0 \%}$ & 23 & 22 & 19 & 9 \\
$\mathbf{4 0 \%}$ & 26 & 23 & 20 & 12 \\
\hline K(+)Tetrasiklin & \multicolumn{5}{c}{$\mathbf{2 4}$} \\
K(-) Akuades & \multicolumn{5}{c}{0} \\
\hline
\end{tabular}


Hasil uji efektivitas antibakteri sabun antiseptik A, B, C dan D terhadap Salmonella typhi pada sabun antiseptik $A$ dengan konsentrasi masing-masing 10\%, 20\%, 30\% dan $40 \%$ dengan rata-rata diameter zona hambat sebesar $13 \mathrm{~mm}, 16 \mathrm{~mm}, 18 \mathrm{~mm}$ dan $20 \mathrm{~mm}$. Sedangkan pada sabun antiseptik B pada konsentrasi masing-masing 10\%, 20\%, 30\% dan $40 \%$ dengan rata-rata diameter zona hambat sebesar $10 \mathrm{~mm}, 11 \mathrm{~mm}, 12 \mathrm{~mm}$ dan $13 \mathrm{~mm}$. Pada sabun antiseptik $C$ dengan konsentrasi masing-masing $10 \%, 20 \%, 30 \%$ dan $40 \%$ dengan rata-rata diameter zona hambat sebesar 15 $\mathrm{mm}, 17 \mathrm{~mm}, 18 \mathrm{~mm}$ dan $19 \mathrm{~mm}$ serta pada sabun antiseptik $D$ pada konsentrasi masingmasing $10 \%, 20 \%, 30 \%$ dan $40 \%$ dengan ratarata diameter zona hambat sebesar $14 \mathrm{~mm}, 15$ $\mathrm{mm}, 16 \mathrm{~mm}$ dan $18 \mathrm{~mm}$. Rata-rata diameter zona hambat paling besar adalah pada sabun antiseptik $A$ dengan konsentrasi $40 \%$ yaitu 20 $\mathrm{mm}$ dan rata-rata diameter zona hambat paling kecil adalah pada sabun antiseptik B dengan konsenstrasi $10 \%$ yaitu $10 \mathrm{~mm}$. Pada kontrol positif (Tetrasiklin) didapatkan rata-rata diameter zona hambat sebesar $32 \mathrm{~mm}$, sedangkan pada kontrol negatif tidak terdapat zona hambat.

Tabel 3. Hasil diameter zona hambat sabun antiseptik A, B, C dan D terhadap bakteri Salmonella typhi

\begin{tabular}{|c|c|c|c|c|c|c|c|c|c|c|c|c|}
\hline \multirow{3}{*}{ Perlakuan } & \multicolumn{12}{|c|}{ Diameter Zona Hambat (mm) Terhadap Salmonella typhi } \\
\hline & \multicolumn{3}{|c|}{ Sabun A } & \multicolumn{3}{|c|}{ Sabun B } & \multicolumn{3}{|c|}{ Sabun C } & \multicolumn{3}{|c|}{ Sabun D } \\
\hline & $\mathbf{I}$ & II & III & $\mathbf{I}$ & II & III & $\mathbf{I}$ & II & III & $\mathbf{I}$ & II & III \\
\hline $10 \%$ & 13 & 14 & 12 & 11 & 10 & 10 & 11 & 15 & 18 & 17 & 9 & 15 \\
\hline $20 \%$ & 16 & 17 & 14 & 13 & 10 & 11 & 15 & 16 & 20 & 17 & 11 & 16 \\
\hline $30 \%$ & 19 & 19 & 17 & 14 & 12 & 11 & 18 & 17 & 18 & 16 & 17 & 16 \\
\hline $40 \%$ & 19 & 18 & 23 & 15 & 12 & 13 & 17 & 19 & 21 & 18 & 16 & 20 \\
\hline $\mathrm{K}(+)$ Tetrasiklin & \multicolumn{12}{|c|}{32} \\
\hline K(-) Akuades & \multicolumn{12}{|c|}{0} \\
\hline
\end{tabular}

Tabel 4. Rata-rata diameter zona hambat sabun antiseptik A, B, C dan D terhadap bakteri Salmonella typhi

\begin{tabular}{ccccc}
\hline \multirow{2}{*}{ Konsentrasi } & \multicolumn{4}{c}{ Rata-Rata Diameter Zona Hambat (mm) terhadap } \\
& \multicolumn{5}{c}{ Salmonella typhi } \\
\cline { 2 - 5 } & Sabun A & Sabun B & Sabun C & Sabun D \\
\hline $\mathbf{1 0 \%}$ & 13 & 10 & 15 & 14 \\
$\mathbf{2 0 \%}$ & 16 & 11 & 17 & 15 \\
$\mathbf{3 0 \%}$ & 18 & 12 & 18 & 16 \\
$\mathbf{4 0 \%}$ & 20 & 13 & 19 & 18 \\
\hline K(+)Tetrasiklin & \multicolumn{5}{c}{32} \\
K(-) Akuades & & & 0 & \\
\hline
\end{tabular}

Pada gambar 1 dapat dilihat bahwa sabun antiseptik dengan konsentrasi yang berbeda memiliki rata-rata diameter zona hambat yang berbeda terhadap bakteri Escherichia coli dan Salmonella typhi. Semakin tinggi konsentrasi sabun antiseptik, zona hambat yang dihasilkan juga semakin lebar. Rata-rata diameter zona hambat pada Escherichia coli lebih besar dibandingkan dengan Salmonella typhi. Hal ini juga menunjukkan bahwa sabun antiseptik memiliki efektivitas antibakteri yang lebih tinggi pada Escherichia coli dibandingkan dengan Salmonella typhi. Semakin tinggi konsentrasi sabun antiseptik, maka semakin besar daya antibakterinya.

Dari uji Kruskal Wallis, sabun A mendapatkan nilai $p=0,013$, sabun $B$ mendapatkan nilai $p=0,048$, sabun $C$ mendapatkan nilai $p=0,044$ dan sabun $D$ mendapatkan nilai $p=0,021$ terhadap Escherichia coli. Sabun A mendapatkan nilai $p=0,007$ sabun $B$ mendapatkan nilai $p=0,027$, sabun $C$ mendapatkan nilai $p=0,020$ dan sabun $D$ mendapatkan nilai $p=0,010$ terhadap Salmonella typhi. Dapat disimpulkan bahwa ada hubungan variabel senyawa triclosan, chlorxylenol, triclocarban dan sodium ben- 
zoate terhadap pertumbuhan bakteri Esche- richia coli dan Salmonella typhi.

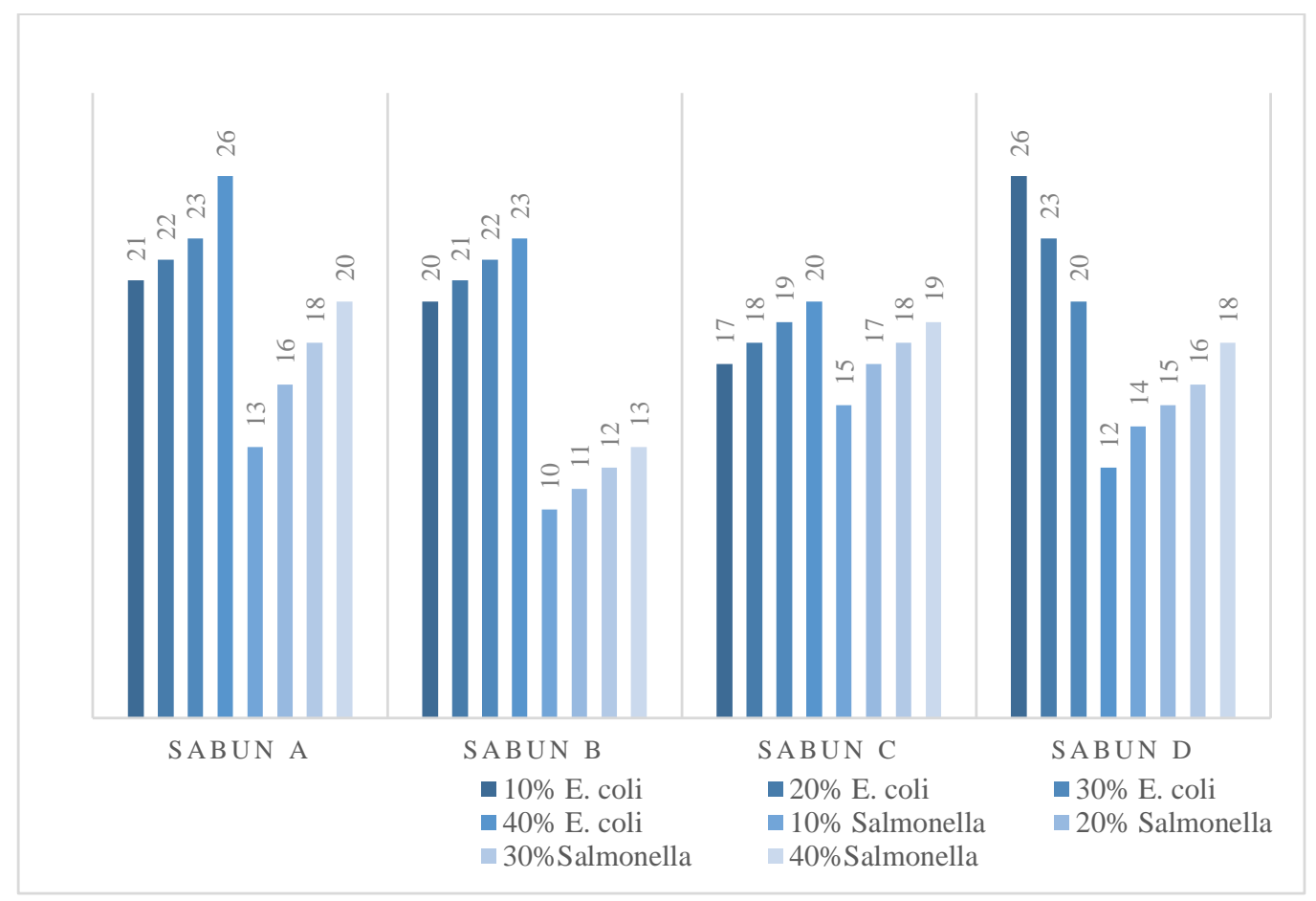

Gambar 1. Grafik perbandingan hasil rata-rata sabun antiseptik A, B, C dan D yang membentuk diameter zona hambat pada Escherichia coli dan Salmonella typhi

\section{Pembahasan}

Mencuci tangan yang benar dengan sabun antiseptik dapat mencegah transmisi dari bakteri patogen yang kemudian dapat menyebabkan infeksi di tubuh manusia. Sabun antiseptik mengandung antimikrobial seperti senyawa triclosan, chlorxylenol, triclocarban dan sodium benzoate yang ditambahkan ke dalam sabun untuk membunuh bakteri dengan cara melisiskan membran dari bakteri patogen. Sabun antiseptik yang mengandung zat kimia seperti triclosan, chloroxylenol dan triclocarban dengan konsentrasi 50\% sudah mampu menghambat pertumbuhan bakteri patogen. Mekanisme antibakteri senyawa triclosan, chlorxylenol, triclocarban dan sodium benzoate diduga dapat mendenaturisasi protein sel bakteri dan merusak membran sel tanpa dapat diperbaiki lagi. ${ }^{13}$

Hasil penelitian berdasarkan klasifikasi zona hambat Greenwood (1995) didapatkan bahwa suspensi sabun antiseptik $A, B, C$ dan $D$ memiliki efektivitas antibakteri terhadap Escherichia coli dan Salmonella tyhpi. Pada hasil penelitian ini menunjukkan bahwa sabun antiseptik A memiliki diameter zona hambat yang besar terhadap Escherichia coli dan Salmonella typhi jika dibandingkan dengan sabun lain. Hal ini mungkin terjadi karena kandungan bahan aktif yang berbeda dari ke empat sabun tersebut. Sabun A mengandung sodium benzoate sedangkan sabun $B$ hanya mengandung triclosan dan sabun $\mathrm{C}$ mengandung chloroxylenol serta sabun D mengandung triclocarban. Menurut Rahardjo (2008) sodium benzoate tidak berwarna, berbentuk cairan dan berbau aromatik yang ringan. Biasa ditambahkan ke sabun, parfum dan juga bidang industri. Sodium benzoate biasa digunakan sebagai antiseptik karena memiliki sifat bakteriostatik. ${ }^{14}$

Pada penelitian ini juga menunjukkan bahwa diameter zona hambat yang terbentuk dari bakteri Escherichia coli dan Salmonella typhi memiliki diameter yang berbeda. Perbedaan besarnya zona hambat diduga dipengaruji oleh struktur dinding sel antara bakteri Escherichia coli dan Salmonella typhi dimana menurut Campbell et al. (1996) bahwa dinding sel bakteri gram negatif mengandung lipopolisakarida yang membantu bakteri dalam melindungi diri dari antibiotik dengan cara menghalangi masuknya antibtiotik. Adapun 
penelitian yang menyatakan bahwa adanya variasi besar zona hambat yang diperoleh dalam penelitian disebabkan oleh masing-masing bakteri memiliki struktur kimia, komposisi dan kandungan yang berbeda. ${ }^{15}$

Pada Escherichia coli, daya hambat yang dimiliki sabun antiseptik $A$ dengan konsentrasi $10 \%, 20 \%, 30 \%$ dan $40 \%$ tergolong dalam kategori kuat sedangkan daya hambat pada sabun antiseptik B terhadap Escherichia coli pada konsentrasi $10 \%, 20 \%, 30 \%$ dan $40 \%$ tergolong dalam kategori kuat. Daya hambat pada sabun antiseptik $C$ terhadap Escherichia coli pada konsentrasi 10\%, 20\%, 30\% tergolong dalam kategori sedang dan $40 \%$ tergolong dalam kategori kuat serta daya hambat sabun antiseptik D terhadap Escherichia coli pada konsentrasi $10 \%$ dan $20 \%$ dan $30 \%$ tergolong dalam kategori tidak ada kemampuan menghambat dan pada konsentrasi $40 \%$ tergolong dalam kategori lemah.

Sedangkan pada Salmonella typhi daya hambat yang dimiliki sabun antiseptik A terhadap Salmonella typhi pada konsentrasi $10 \%$ tergolong lemah, $20 \%$ dan $30 \%$ tergolong dalam kategori sedang dan $40 \%$ tergolong dalam kategori kuat sedangkan daya hambat pada sabun antiseptik B terhadap Salmonella typhi pada konsentrasi 10\%, 20\%, 30\% dan 40\% tergolong dalam kategori lemah. Daya hambat pada sabun antiseptik $C$ terhadap Salmonella typhi pada konsentrasi 10\%, 20\%, 30\% dan 40\% tergolong dalam kategori sedang serta daya hambat sabun antiseptik D terhadap Salmonella typhi pada konsentrasi $10 \%$ tergolong lemah sedangkan $20 \%$, 30\% dan $40 \%$ tergolong dalam kategori sedang.

Pada kontrol positif menggunakan tetrasiklin tergolong dalam kategori kuat pada Escherichia coli dan Salmonella typhi dengan rata-rata diameter zona hambat sebesar $24 \mathrm{~mm}$ dan 32 $\mathrm{mm}$. Sedangkan kontrol negatif dengan akuades tidak dapat menghambat pertumbuhan bakteri.

Tabel 5. Klasifikasi Zona Hambat Berdasarkan Greenwood $^{16}$

\begin{tabular}{cc}
\hline $\begin{array}{c}\text { Rata-Rata Diameter } \\
\text { Zona Hambat }\end{array}$ & $\begin{array}{c}\text { Respon Hambatan } \\
\text { Pertumbuhan }\end{array}$ \\
\hline$>20 \mathrm{~mm}$ & Kuat \\
$16-20 \mathrm{~mm}$ & Sedang \\
$11-15 \mathrm{~mm}$ & Lemah \\
$<10 \mathrm{~mm}$ & Tidak Ada \\
\hline
\end{tabular}

Apabila diameter zona hambat lebih besar dari $20 \mathrm{~mm}$ maka respon hambatan pertumbuhannya sangat kuat sedangkan respon hambatan pertumbuhan dinyatakan lemah jika diameter zona hambat $\leq 5 \mathrm{~mm}$. Hasil penelitian suspensi sabun antiseptik A, B, C dan D menunjukkan bahwa 4 sampel sabun antiseptik dengan konsentrasi masing-masing 10\%, 20\%, $30 \%$ dan $40 \%$ dan fenol $2 \%$ memiliki efektivitas antibakteri terhadap bakteri gram negatif yaitu Escherichia coli dan Salmonella typhi. Selain itu, penelitian ini juga menunjukkan bahwa efektivitas suatu zat antimikroba dapat dipengaruhi oleh konsentrasi zat yang diberikan. Semakin tinggi konsentrasi sabun antiseptik semakin tinggi juga kandungan bahan aktif yang berfungsi sebagai antimikroba sehingga kemampuan untuk menghambat pertumbuhan bakteri juga semakin besar (Brooks et al., 2008). Zona hambat yang dibentuk oleh tetrasiklin menunjukkan respon hambatan pertumbuhan yang kuat. Sedangkan pada akuades tidak ada respon hambatan pertumbuhan karena memiliki diameter zona hambat $5,00 \mathrm{~mm}$ yang merupakan diameter dari cakram tersebut.

Hasil penelitian ini senada dengan hasil penelitian yang telah dilakukan oleh Fitri (2010) dimana peneliti menggunakan 4 sabun antiseptik dengan konsentrasi $50 \%$ untuk menguji efektivitas antibakterinya terhadap bakteri Staphylococcus aureus dan Escherichia coli dan didapati bahwa 4 sampel sabun antiseptik pada konsentrasi $50 \%$ dapat menghambat pertumbuhan bakteri tersebut dan rata-rata diameter zona hambat adalah sebesar $15,6 \mathrm{~mm}, 11,5 \mathrm{~mm}, 9,83 \mathrm{~mm}$ dan 25,16 $\mathrm{mm} .{ }^{11}$

\section{Kesimpulan}

Sabun antiseptik mempunyai efektivitas antibakteri terhadap pertumbuhan bakteri Escherichia coli dan Salmonella typhi, sabun antiseptik mempunyai efektivitas antibakteri terhadap pertumbuhan bakteri Escherichia coli dan Salmonella typhi pada konsentrasi $10 \%, 20 \%$, $30 \%$ dan $40 \%$. Semakin tinggi konsentrasi dari sabun antiseptik, semakin tinggi juga daya hambatnya. Hasil uji Kruskal Wallis menunjukkan bahwa ada hubungan variabel senyawa triclosan, chloroxylenol, triclocarban, dan sodium benzoate terhadap pertumbuhan bakteri 
Escherichia coli dan Salmonella typhi.

\section{Referensi}

1. Bonheur JL, Arya M, Tamer MA, Anand BS, Bank S, Frye RE, Lee JG, Talavera F. 2015. Practice Essentials, Background and Etiology of Bacterial Gastroenteritis. Medscape. https://emedicine.medscape.com/article/ 176400-overview

2. Burton $M$, Cobb E, Donachie $P$, Judah $G$, Curtis V, Schimdt W. 2011. The Effect of Handwashing with Water or Soap on Bacterial Contamination of Hands. Int. J. Environ. Res. Public Health 8 (1): 97-104 https://dx.doi.org/10.3390\%2Fijerph8010 097

3. Tate JE, Burton AH, Boschi-Pinto C, Steele AD, Duque J, Parashar UD. 2012. 2008 estimate of worldwide rotavirusassociated mortality in children younger than 5 years before the introduction of universal rotavirus vaccination programmes: a systematic review and meta-analysis. Lancet Infect Dis. 12(2):136141. doi:10.1016/S1473-3099(11)70253-5

4. Jawetz MA. 2010. Mikrobiologi Kedokteran (25 ed.). New York: Mc Graw Hill

5. Kementerian Kesehatan. 2015. Profil Kesehatan Indonesia 2014. Jakarta

6. Zein U, Sagala KH, Ginting J. 2004. Diare Akut Disebabkan Bakteri. e-USU Repository

7. Crump JA, Sjölund-Karlsson M, Gordon MA, Parry CM. 2015. Epidemiology, Clinical Presentation, Laboratory Diagnosis, Antimicrobial Resistance, and Antimicrobial Management of Invasive Salmonella Infections. Clin Microbiol Rev 28(4):901-937. doi:10.1128/CMR.0000215

8. Departemen Kesehatan. 2013. Sistematika Pedoman Pengendalian Penyakit Demam Tifoid. Jakarta: Direktorat Jendral
Pengendalian Penyakit \& Penyehatan Lingkungan. Jakarta

9. Departemen Kesehatan. 2010. Profil Kesehatan Indonesia, Jakarta: Departemen Kesehatan Republik Indonesia. Jakarta

10. Central of Disease Control and Prevention. 2015. Handwashing in Community Settings.

https://www.cdc.gov/handwashing/pdf/w ash-your-hands-fact-sheet-508.pdf

11. Fitri L. 2010. Kemampuan Daya Hambat Beberapa Macam Sabun Antiseptik Terhadap Pertumbuhan Staphylococcus aureus dan Esherichia Coli. Jurnal Biologi Edukasi 2(2)

12. Pratama MR. 2005. Pengaruh Ekstrak Serbuk Kayu Siwak (Salvadora persica) Terhadap Pertumbuhan Bakteri Streptococcus mutans dan Staphylococcus aureus Dengan Metode Difusi Agar. Institut Pertanian Bogor

13. Gattuso G, Barreca D, Gargiulli C, Leuzzi U, Caristi C. 2007. Flavonoid composition of Citrus juices. Molecules 12(8):1641-1673. doi:10.3390/12081641

14. Rahardjo ID. 2007. Sensitivitas Staphylococcus aureus Sebagai Bakteri Patogen Penyebab Mastitis Terhadap Antiseptika Pencelup Puting Sapi Perah. Jurnal Protein, 4(1): 31-36

15. Dharmawan IWE, Retno K, Made SP. 2009. Isolasi Streptomyces Spp. Pada Kawasan Hutan Provinsi Bali Serta Uji Daya Hambatnya Terhadap Lima Strain Diarrhegenic Escherichia coli. Jurnal Biologi XIII (1): 1-6

16. Greenwood D. 1995. Antibiotics, Susceptibility (Sensitivity) Test Antimicrobial And Chemoterapy. Mc. Graw Hill Company. USA. 